\title{
Antibody response of rainbow trout with single or double infections involving viral haemorrhagic septicaemia virus and infectious haematopoietic necrosis virus
}

\author{
J. M. Fregeneda-Grandes ${ }^{1,2}$, H. F. Skall ${ }^{1}$, N. J. Olesen ${ }^{1, *}$ \\ ${ }^{1}$ National Veterinary Institute, Technical University of Denmark, Hangøvej 2, 8200 Århus N, Denmark. \\ ${ }^{2}$ Present address: Departamento de Sanidad Animal, Universidad de León, 24071 León, Spain
}

\begin{abstract}
Juvenile rainbow trout Oncorhynchus mykiss were experimentally infected by immersion with viral haemorrhagic septicaemia virus (VHSV), infectious haematopoietic necrosis virus (IHNV) or with both viruses. The presence of neutralizing antibodies in the sera of infected fish were analysed by $50 \%$ plaque neutralization tests (50\%PNT). In Group 1 (infected with VHSV) and Group 2 (infected with IHNV) neutralizing antibodies were found in $41 \%$ and $21 \%$ of the serum samples, respectively. No cross-reacting antibodies were found in these 2 groups. In Group 3 (infected with both viruses) $30 \%$ of the samples showed neutralizing antibodies against VHSV, $21 \%$ against IHNV and $12 \%$ against both viruses. Fish in Group 3 developed a double specific antibody reaction whose kinetics and intensity (mean of $\log _{10}$ titres) were similar to the antibody response of the single infected groups.
\end{abstract}

KEY WORDS: VHSV $\cdot$ IHNV $\cdot$ Fish $\cdot$ Antibody response $\cdot$ Rainbow trout

\section{INTRODUCTION}

Viral haemorrhagic septicaemia virus (VHSV) and infectious haematopoietic necrosis virus (IHNV) are important viral agents affecting a range of fish species, and disease outbreaks cause major losses in European aquaculture. There are many similarities between the 2 viruses and the diseases they cause. Both VHSV and IHNV are enveloped non-segmented negative-strand RNA viruses belonging to the genus Novirhabdovirus of the Rhabdoviridae family (Walker et al. 2000), they have a similar order of genes and possibly share some cross-reacting epitopes sufficiently alike to be recognised by fish antibodies (Vestergård Jørgensen et al. 1991). Specific poly- and monoclonal antibodies as well as various molecular methods, however, provide possibilities for easy differentiation between them (Lorenzen et al. 1988, Ris- tow et al. 1991, Winton \& Einer-Jensen 2002). The pathologic changes observed during VHS or IHN outbreaks in farmed salmonids are very similar. The affected fish show lethargy, exophthalmia, darkening of the body, pale gills and haemorrhages in the skin and eyes. Ascites can occasionally be seen and in chronic stages dark discolouration and abnormal swimming behaviour may be observed (Wolf 1988). Mortality depends on the age of the fish but may be up to $100 \%$ in fry, although often less in older fish, typically from 30 to $70 \%$. Whereas VHS has occurred endemically in farmed rainbow trout in the continental part of Europe for more than $50 \mathrm{yr}$, it was only recently, in 1987, that IHN was introduced into Europe (BaudinLaurencin 1987, Bovo et al. 1987) probably by direct or indirect importation from USA (Enzmann et al. 2005). Since then, IHN has spread to several countries in Continental Europe where there have been many 
cases of farmed rainbow trout being co-infected with VHSV and IHNV (J. Castric \& G. Bovo pers. comm.).

Interactions between viruses during double or simultaneous infection have been studied thoroughly in mammals (Younger \& Whitaker-Dowling 1994). These studies have shown that viruses can interact during coinfection, resulting in stimulatory or inhibitory effects on viral replication. However, in fish, a limited number of viral co-infection interference studies have been reported and they are mainly concerned with co-infection of IHNV and infectious pancreatic necrosis virus (IPNV) (Chinchar et al. 1998, Alonso et al. 1999, 2003, Tafalla et al. 2006, Byrne et al. 2008). To our knowledge the only studies that characterize the interactions between VHSV and IHNV during co-infection were conducted by Brudeseth et al. (2002) and de las Heras et al. (2008). These studies showed that simultaneous exposure to both viruses results in some degree of interaction at the cellular level and that IHNV replication was affected by the presence of VHSV. No similar studies have, however, been published on the putative interaction in the antibody response after dual infections with VHSV and IHNV.

Studies on antibody response against VHSV and IHNV in rainbow trout have demonstrated the efficacy of different serological techniques for the detection and characterization of antibodies against salmonid rhabdoviruses under experimental and field conditions (Olesen \& Vestergård Jørgensen 1986, HattenbergerBaudouy et al. 1989, Olesen et al. 1991, Vestergård Jørgensen et al. 1991). Hattenberger-Baudouy et al. (1989) demonstrated that the same fish could harbour neutralizing antibodies against both VHSV and IHNV. More recently, Boudinot et al. (1998) showed that after a combined DNA immunization with the glycoprotein gene of VHSV and IHNV the fish developed an antibody reaction to both viruses whose kinetics and intensity were similar to those observed by single immunization.

The aim of this research was to study the kinetics of antibody response in rainbow trout experimentally infected with either VHSV, IHNV or with the 2 viruses, to determine if the viruses in single or double infection have different effects on antibody response.

\section{MATERIALS AND METHODS}

Experimental infection. Juvenile rainbow trout Oncorhynchus mykiss (Walbaum) of approximately $50 \mathrm{~g}$ were obtained from a certified VHS- and IHN-free trout farm and were acclimatised to laboratory conditions for $2 \mathrm{wk}$. The fish were approximately $8 \mathrm{mo}$ at the start of infection. For the challenge experiment, the fish were divided into 4 groups (50 fish group ${ }^{-1}$ ). Each group was infected by immersion for $2 \mathrm{~h}$ with either VHSV isolate DK-201433-40 (harvested after 2 cell culture passages in BF-2 cells) obtained from an infected rainbow trout farm (Fregeneda-Grandes \& Olesen 2007) or the first French IHNV isolate 32.87 (Hattenberger-Baudouy et al. 1989) (harvested after 8 cell culture passages in EPC cells). Group 1 was infected with $2 \times 10^{5} \mathrm{TCID}_{50} \mathrm{ml}^{-1}$ water of VHSV, Group 2 with $6.5 \times$ $10^{4} \mathrm{TCID}_{50} \mathrm{ml}^{-1}$ water of IHNV and Group 3 with $6.5 \times$ $10^{4} \mathrm{TCID}_{50} \mathrm{ml}^{-1}$ water of IHNV and $6 \mathrm{~d}$ later with $2 \times$ $10^{5} \mathrm{TCID}_{50} \mathrm{ml}^{-1}$ water of VHSV. The non-infected control group (Group 4) was immersed in water supplemented with $20 \mathrm{ml}$ cell culture medium and handled as the infected groups. The experiment was carried out in $120 \mathrm{l}$ glass tanks. Water temperature was maintained at $12 \pm 2{ }^{\circ} \mathrm{C}$ with constant aeration, the photoperiod was set for $12 \mathrm{~h}$ of daylight and the fish were fed daily with a commercial pellet diet. Mortality among the different groups was recorded daily and organ samples (head kidney, spleen and heart) were collected from dead fish for virological examination.

Virus detection. Organ samples were prepared and processed according to Mortensen et al. (1999). In case of cytopathic effect the virus collected from cell culture supernatants was identified by ELISA. VHSV-ELISA was done according to Olesen \& Jørgensen (1991) with modifications described by Mortensen et al. (1999). IHNV-ELISA was done as described for VHSV-ELISA with the modification that the wells were coated with protein-A purified rabbit anti-IHNV and instead of the anti-VHSV monoclonal antibody (MAb) IP5B11, antiIHNV MAb hyb 136-3 was used. Titration of the viruses was carried out according to the $50 \%$ tissue culture infective dose method (Kärber 1931) onto BF-2 and EPC cells in 96-well plates and expressed as TCID $_{50} \mathrm{ml}^{-1}$ water for infection doses and as TCID $50 \mathrm{~g}^{-1}$ in fish tissues.

Antibody detection. Blood samples were collected by puncture of the caudal vein. Up to 25 rainbow trout were sampled from each group. The fish were bled 2 , $4,6,8$, and $10 \mathrm{wk}$ after the first infection such that in the case of Group 3, infected with the 2 viruses, the fish were actually sampled 1, 3, 5, 7 and 9 wk after VHSV infection. After clotting overnight at $4^{\circ} \mathrm{C}$ the blood samples were centrifuged at $1000 \times \mathrm{g}$ for $45 \mathrm{~min}$ at $4^{\circ} \mathrm{C}$ to obtain the serum. The sera were heat treated at $45^{\circ} \mathrm{C}$ for $30 \mathrm{~min}$ and stored at $-20^{\circ} \mathrm{C}$ until use.

Neutralizing antibodies, directed against VHSV and IHNV, present in the trout sera were detected by $50 \%$ plaque neutralization tests (50\%PNT). The tests were performed in 96-well microtitre plates as described previously (Olesen \& Vestergård Jørgensen 1986) and modified by Fregeneda-Grandes \& Olesen (2007) using the same virus isolates in the $50 \%$ PNT as in the experimental infection. Briefly, $0.05 \mathrm{ml}\left(\right.$ well $\left.^{-1}\right)$ of serial 2- 
fold dilutions of trout serum in dilution medium (Eagle's MEM with Tris buffer and $5 \%$ foetal bovine serum), beginning with a dilution ratio of $1: 10$, were mixed in round bottom, 96-well microplates (Nunc) with an equal volume of trout complement diluted to 1:30. After incubation for $30 \mathrm{~min}$ at $15^{\circ} \mathrm{C}$ on a rocker platform, $0.1 \mathrm{ml}$ of virus dilution adjusted to $8 \times 10^{3}$ PFU ml ${ }^{-1}$ was added to each well and the plate was incubated overnight at $15^{\circ} \mathrm{C}$ on a rocker platform. Each serum-complement-virus mixture was then adsorbed to 2 replicate wells $\left(0.01 \mathrm{ml}\right.$ well $\left.{ }^{-1}\right)$ with monolayer EPC cells in 96-well microplates (Life Technologies) for $1 \mathrm{~h}$ at $15^{\circ} \mathrm{C}$. The cell cultures were then overlaid with $1 \%$ methyl cellulose in plaque medium (double concentrated Eagle's MEM with Tris buffer and $4 \%$ foetal bovine serum) and incubated for $5 \mathrm{~d}$ at $15^{\circ} \mathrm{C}$. Finally, the cells were fixed in $10 \%$ P-buffered formaldehyde $\left(0.15 \mathrm{ml}\right.$ well $^{-1}, 3 \mathrm{~h}$ at room temperature), followed by 10 washes with tap water and staining with $0.5 \%$ crystal violet $\left(0.05 \mathrm{ml} \mathrm{well}^{-1}, 30 \mathrm{~min}\right.$ at room temperature). After 10 more washes, the microplates were air-dried and the plaques counted by placing the plates on a light table. The $50 \%$ PNT titre was calculated as the reciprocal value of the highest trout serum dilution causing $50 \%$ reduction of the average number of plaques in control cultures inoculated with normal trout serum, complement and virus. Since it has been reported that some sera exhibit unspecific reaction at low titres (Olesen \& Vestergård Jørgensen 1986), only PNT titres of 160 or higher were considered positive.

Statistics. Differences in cumulative mortality and the presence of neutralizing antibodies between the single or double infected groups were analysed statistically by the chi-square $\left(\chi^{2}\right)$ test. For statistical analysis titres were transformed to a logarithmic scale and differences in mean $\log _{10}$ titres for positive fish against homologous virus between the single or double infected groups, were analysed using the parametric ANOVA test or non-parametric Kruskall-Wallis test, depending on whether the conditions for the classical analysis of variance were fulfilled or not. True comparison was only possible for groups infected with IHNV (Groups 2 and 3) because in the case of VHSV infected groups (Groups 1 and 3), weekly samplings between the 2 groups were not the same. All statistical tests were done with Epi Info (TM) software for Windows, Version 3.3 (Dean et al. 2002) and p < 0.05 was taken as the level of significance.

\section{RESULTS}

Rainbow trout in the 3 infected groups showed the classic signs of virus infection such as lethargy, darkening of the body, abnormal swimming, exophthalmia, ascites and haemorrhages in the skin. While attempts were made to make the infection dose $10^{5} \mathrm{TCID}_{50} \mathrm{ml}^{-1}$ for both viruses, titration of the doses yielded viral titres of 4.8 and $5.3 \log _{10}$ for IHNV and VHSV, respectively. Cumulative mortality at the end of the experiment (70 d post-infection [p.i.]) was $58 \%$ and $52 \%$ for the fish infected with VHSV and IHNV, respectively (Fig. 1). A lower mortality (46\%) was observed in the group infected with both viruses, but the difference was not statistically significant. Cumulative mortality in the control group was $10 \%$ and all fish in this group were negative by virological examination. In fish infected with VHSV or IHNV, the homologous virus was isolated and identified by ELISA (Table 1). From single virus infected rainbow trout, VHSV was isolated from 15 out of 29 fish (52\%) and IHNV from 11 out of 26 fish (42\%). In fish infected with both viruses, IHNV was only detected up to $17 \mathrm{~d}$ p.i. hereafter only VHSV was detected. Both viruses were not isolated from any of the fish at the same time. In this group, 3 out of 23 $(13 \%)$ were positive for IHNV, 9 out of 23 (39\%) for VHSV and, in total, virus was isolated from 12 out of 23 fish $(52 \%)$. Individual virus titres varied significantly among fish in the 3 groups (ranging from $2.7 \times 10^{3}$ to $2.7 \times 10^{9} \mathrm{TCID}_{50} \mathrm{~g}^{-1}$ ) but no statistical differences in mean $\log _{10}$ titres were found when double infected fish were compared with single infected fish despite the fact that mean titres were 2 logarithmic units lower for IHNV in the double infected group (Table 1).

The first antibody response was found in the IHNV infected Group 2 wk p.i. in $8 \%$ of the fish. The first antibody response against VHSV was detected 4 wk p.i. in $40 \%$ of the fish in the single infected group. In

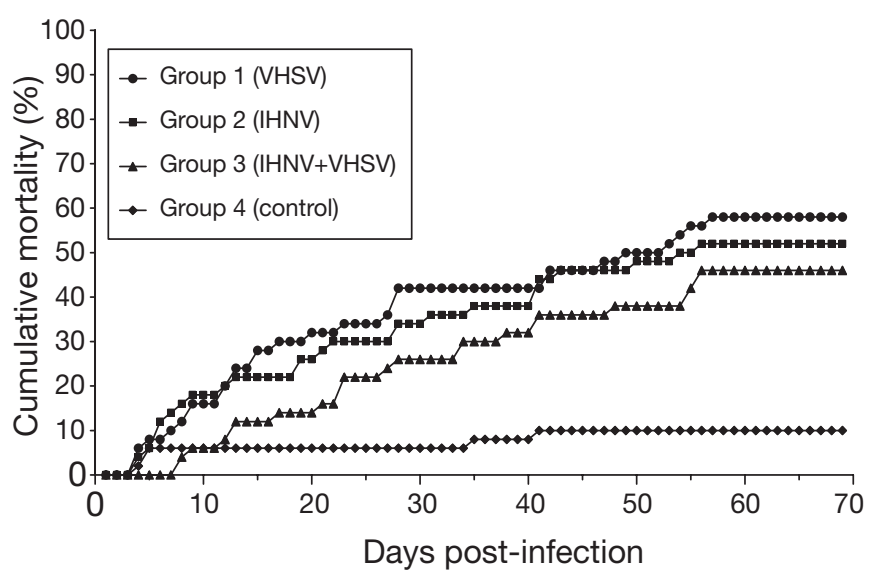

Fig. 1. Cumulative mortality (\%) of 4 groups of 50 rainbow trout Oncorhynchus mykiss single or double infected with viral haemorrhagic septicaemia virus (VHSV) or infectious haematopoietic necrosis virus (IHNV). Group 1: infected with $2 \times 10^{5} \mathrm{TCID}_{50} \mathrm{ml}^{-1}$ water of VHSV; Group 2: infected with $6.5 \times 10^{4} \mathrm{TCID}_{50} \mathrm{ml}^{-1}$ water of IHNV; Group 3: infected with $6.5 \times 10^{4} \mathrm{TCID}_{50} \mathrm{ml}^{-1}$ water of IHNV and $2 \times 10^{5} \mathrm{TCID}_{50} \mathrm{ml}^{-1}$ water of VHSV 6 d later; Group 4: not infected 
Table 1. Virus isolation and infectious titres in rainbow trout Oncorhynchus mykiss experimentally infected with viral haemorrhagic septicaemia virus (VHSV, Group 1), infectious haematopoietic necrosis virus (IHNV, Group 2) and both viruses (Group 3). In case of double infection, the weeks post-infection (p.i.) for VHSV are 1, 3, 5, 7 and 9. 'Positive for' columns show number of positive fish out of the total dead fish tested for each $2 \mathrm{wk}$ period

\begin{tabular}{|c|c|c|c|c|c|c|c|c|}
\hline \multirow{2}{*}{ Weeks p.i. } & \multicolumn{2}{|c|}{- Group $1 \longleftarrow$} & \multicolumn{2}{|c|}{- Group $2 \longleftarrow$} & \multicolumn{4}{|c|}{ Group 3} \\
\hline & $\begin{array}{l}\text { Positive for } \\
\text { VHSV }\end{array}$ & $\begin{array}{l}\text { Mean titre } \\
\left(\text { TCID }_{50} \mathrm{~g}^{-1}\right)\end{array}$ & $\begin{array}{l}\text { Positive for } \\
\text { IHNV }\end{array}$ & $\begin{array}{l}\text { Mean titre } \\
\left(\text { TCID }_{50} \mathrm{~g}^{-1}\right)\end{array}$ & $\begin{array}{l}\text { Positive for } \\
\text { VHSV }\end{array}$ & $\begin{array}{l}\text { Mean titre } \\
\left(\text { TCID }_{50} \mathrm{~g}^{-1}\right)\end{array}$ & $\begin{array}{l}\text { Positive for } \\
\text { IHNV }\end{array}$ & $\begin{array}{l}\text { Mean titre } \\
\left(\text { TCID }_{50} \mathrm{~g}^{-1}\right)\end{array}$ \\
\hline 2 & $10 / 14$ & $9.4 \times 10^{6}$ & $9 / 11$ & $8.2 \times 10^{5}$ & $0 / 6$ & - & $3 / 6$ & $4.6 \times 10^{3}$ \\
\hline 4 & $4 / 9$ & $2.7 \times 10^{6}$ & $0 / 4$ & - & $5 / 6$ & $2.0 \times 10^{6}$ & $0 / 6$ & - \\
\hline 6 & $0 / 2$ & - & $2 / 7$ & $5.9 \times 10^{4}$ & $3 / 6$ & $1.7 \times 10^{6}$ & $0 / 6$ & - \\
\hline 8 & $1 / 5$ & $2.7 \times 10^{4}$ & $0 / 3$ & - & $0 / 3$ & - & $0 / 3$ & - \\
\hline 10 & $0 / 1$ & - & $0 / 1$ & - & $1 / 2$ & $1.3 \times 10^{6}$ & $0 / 2$ & - \\
\hline Total & $15 / 29$ & $5.3 \times 10^{6}$ & $11 / 26$ & $5.1 \times 10^{5}$ & $9 / 23$ & $1.8 \times 10^{6}$ & $3 / 23$ & $4.6 \times 10^{3}$ \\
\hline
\end{tabular}

Table 2. Detection of neutralizing antibodies (NAb) by $50 \%$ plaque neutralization test (50\%PNT) in rainbow trout Oncorhynchus mykiss experimentally infected with viral haemorrhagic septicaemia virus (VHSV, Group 1), infectious haematopoietic necrosis virus (IHNV, Group 2) and both viruses (Group 3). Data are: number of sera with titres >160/number of sera tested. In case of double infection, the weeks post-infection (p.i.) for VHSV are 1, 3, 5, 7 and 9

\begin{tabular}{|c|c|c|c|c|c|c|c|}
\hline \multirow[t]{2}{*}{ Weeks p.i. } & \multicolumn{2}{|c|}{ Group 1} & \multicolumn{2}{|c|}{$\longrightarrow$ Group $2 \longleftarrow$} & \multicolumn{3}{|c|}{ - Group 3 - } \\
\hline & $\begin{array}{c}\text { Anti-VHSV } \\
\text { NAb }\end{array}$ & $\begin{array}{c}\text { Anti-IHNV } \\
\text { NAb }\end{array}$ & $\begin{array}{c}\text { Anti-VHSV } \\
\text { NAb }\end{array}$ & $\begin{array}{c}\text { Anti-IHNV } \\
\text { NAb }\end{array}$ & $\begin{array}{c}\text { Anti-VHSV } \\
\text { NAb }\end{array}$ & $\begin{array}{c}\text { Anti-IHNV } \\
\text { NAb }\end{array}$ & $\begin{array}{c}\text { Anti-VHSV+ } \\
\text { IHNV NAb }\end{array}$ \\
\hline 2 & $0 / 25$ & $0 / 25$ & $0 / 25$ & $2 / 25$ & $0 / 25$ & $0 / 25$ & $0 / 25$ \\
\hline 4 & $10 / 25$ & $0 / 25$ & $0 / 24$ & $6 / 24$ & $0 / 25$ & $6 / 25$ & $0 / 25$ \\
\hline 6 & $11 / 21$ & $0 / 21$ & $0 / 25$ & $10 / 25$ & $5 / 25$ & $6 / 25$ & $2 / 25$ \\
\hline 8 & $10 / 16$ & $0 / 16$ & $0 / 22$ & $5 / 22$ & $14 / 25$ & $8 / 25$ & $7 / 25$ \\
\hline 10 & $12 / 18$ & $0 / 18$ & $0 / 21$ & $2 / 21$ & $19 / 25$ & $6 / 25$ & $6 / 25$ \\
\hline Total & $43 / 105$ & $0 / 105$ & $0 / 117$ & $25 / 117$ & $38 / 125$ & $26 / 125$ & $15 / 125$ \\
\hline
\end{tabular}

the double infected group, the first antibody response against IHNV was found 4 wk p.i. in $24 \%$ of the fish, and against VHSV $5 \mathrm{wk}$ after VHSV infection (6 wk after IHNV infection) in $20 \%$ of the fish (Table 2). In all samples taken during the experiment $41 \%$ (43/105) were positive in Group 1, infected with VHSV, and $21 \%$ (25/117) in Group 2, infected with IHNV. Maximum numbers of positives were found in samples taken 10 wk p.i. for Group 1 and in the samples taken 6 wk p.i. for Group 2. No cross-reacting antibodies were found in these 2 groups (Table 1). In the group infected with both viruses (Group 3), 30\% (38/125) of the samples had neutralizing antibodies against VHSV, $21 \%$ (26/125) against IHNV and 12\% (15/125) had neutralizing antibodies against both viruses. Maximum numbers of positives against each or both viruses in Group 3 were found 10 wk p.i. (Table 2). All the samples in the control group were negative (results not shown). Differences in the number of antibody positive fish between the single and double infected IHNV groups were not statistically significant.

The antibody titres of positive fish varied among individuals in the 3 groups from 160 to 20480. In general, higher titres were found against IHNV than against VHSV and the titres in Group 3 were lower than in Groups 1 and 2. However, the mean $\log _{10}$ titres of single or double infected positive fish were similar and differences in mean titres between Group 2 and 3 were significant only for anti-IHNV antibodies at Week $4(F=5.38, \mathrm{p}=0.043)$ (Fig. 2). The highest mean titres were found $8 \mathrm{wk}$ p.i. except for anti-VHSV antibodies in Group 3 that were highest at 9 wk after VHSV infection (10 wk after IHNV infection).

\section{DISCUSSION}

In the present study we challenged rainbow trout with either VHSV, IHNV or both viruses 1 wk apart and compared the differences between single and double infected groups mainly in relation to the production of specific neutralizing antibodies. To avoid a synergistic effect on mortality and to create more 'realistic' infection conditions the double infected group was challenged with VHSV 1 wk after IHNV infection, i.e. starting with the usually less pathogenic IHNV.

The mortality observed in the control group was higher than expected and may be due to repeated blood sampling and handling. Mortality in the infected 

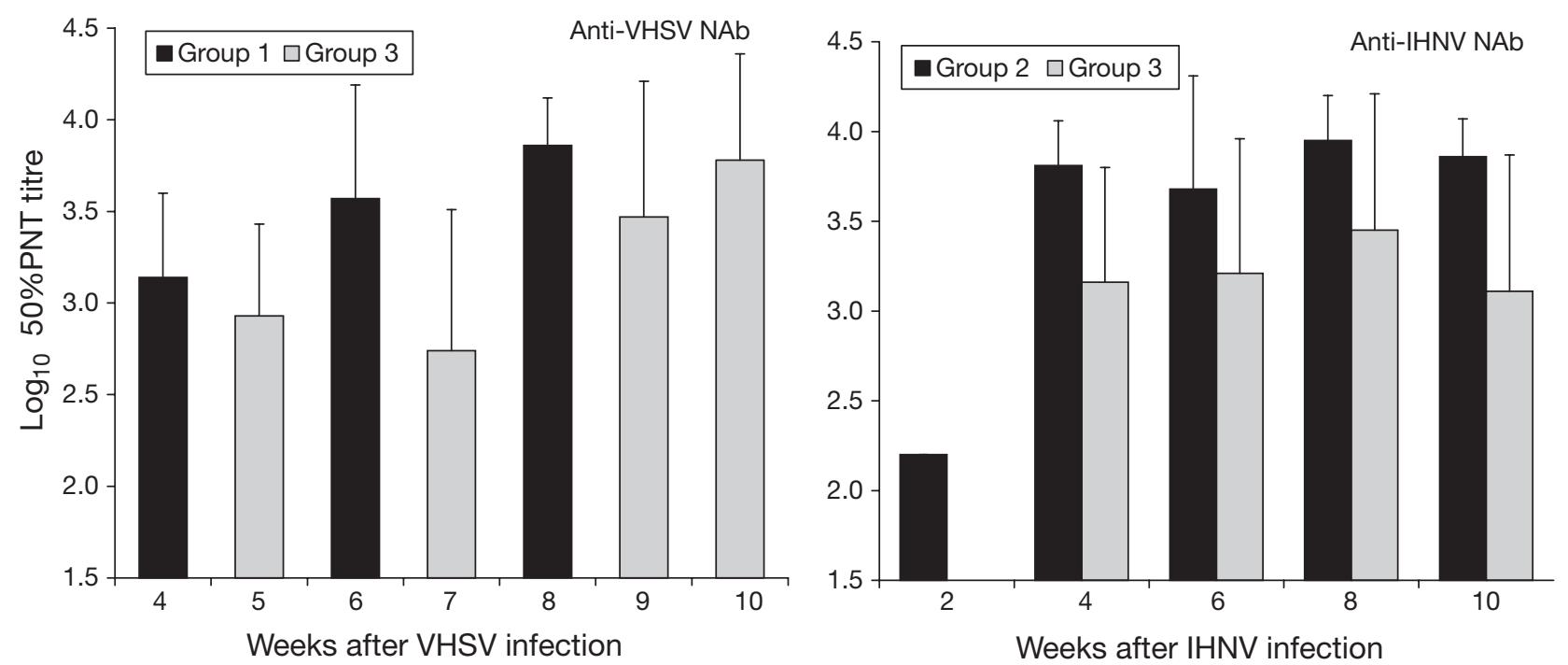

Fig. 2. Mean (+SD) neutralizing antibodies (NAb) titres to viral haemorrhagic septicaemia virus (VHSV) and infectious haematopoietic necrosis virus (IHNV) detected by $50 \%$ plaque neutralization test (50\%PNT) in sera of rainbow trout Oncorhynchus mykiss infected with VHSV (Group 1), IHNV (Group 2) or IHNV-VHSV double infected (Group 3)

groups was approximately $50 \%$ and, in part, was likely to be due to handling rather than to infection as the viruses were isolated from less than half of the fish which died during the trials (Table 1). We observed a reduced cumulative mortality in the double infected group compared to the single-infected groups, although the difference was not statistically significant. A similar protective effect has also been demonstrated by other authors both in naturally or artificially viral co-infected fish (LaPatra et al. 1993a, 1995, Hedrick et al. 1994, Alonso et al. 2003, Parkingking et al. 2003, Byrne et al. 2008). Previous studies showed that IHNV-DNA vaccinated rainbow trout were protected against both IHNV and VHSV infection as early as $1 \mathrm{~d}$ after vaccine injection due to strong stimulation of the non-specific innate immune system (LaPatra et al. 2001, Lorenzen et al. 2002). Thus, in our study, the first IHNV infection might have stimulated nonspecific defence mechanisms against VHSV reducing the mortality rate in the double infected group.

By simultaneous infection of rainbow trout with VHSV and IHNV, Brudeseth et al. (2002) found a more restricted distribution of IHNV in internal organs compared to the single infected fish, supporting the conclusion that viral co-infection results in some degree of interaction at the cellular level. Alonso et al. (1999) demonstrated that IPNV interfered with IHNV replication in vitro in BF-2 cells, as the titre of IHNV decreased 3 logarithmic units in the presence of IPNV and was no longer detected in the cultures after several passages. Recently, de las Heras et al. (2008) examined the cellular interactions of IPNV, VHSV and IHNV in co-infections at the early stages of the infective cycle and showed that IHNV attachment to BF-2 cells was always reduced in the presence of the other viruses and could also be decreased by treatment with chemicals that did not affect VHSV binding. In our study, IHNV was detected in the double infected fish up until $17 \mathrm{~d}$ p.i. Hereafter only VHSV was detected from dead fish in Group 3 both in BF-2 and EPC cells. Moreover, in the organs lower IHNV titres were observed in the double infected group compared with the IHNV single infected group, whereas, the double infection appeared not to have any influence on VHSV replication (Table 1). Various possibilities for the interference of viral replication in co-infections with 2 viruses have been proposed including (1) directly, as a consequence of their own replication and (2) indirectly, due to the induction of anti-viral factors such as interferon or cytokines (Chinchar et al. 1998, Tafalla et al. 2006).

The antibody response of the fish in the single infected groups was similar to that reported previously. In rainbow trout infected by cohabitation under experimental conditions at $10^{\circ} \mathrm{C}$ and $13^{\circ} \mathrm{C}$ anti-VHSV antibodies were observed $4 \mathrm{wk}$ post-exposure and reached a peak at 6 to $10 \mathrm{wk}$, when the mortality had ceased (Olesen \& Vestergård Jørgensen 1986, Olesen et al. 1991). Rainbow trout (mean weight $16 \mathrm{~g}$ ) exposed to waterborne IHNV, which resulted in a $50 \%$ cumulative mortality, exhibited low prevalence and titres of neutralizing antibodies $1 \mathrm{wk}$ p.i., but at $6 \mathrm{wk}$ p.i. $59 \%$ of the fish tested had titres of 2560 (LaPatra et al. 1993b). The results obtained under experimental conditions corroborated those obtained with sera from rainbow trout fingerlings and adults surviving natural outbreaks of VHS or IHN (Vestergård Jørgensen et al. 
1991, Hattenberger-Baudouy et al. 1989). In this later study, the authors demonstrated that 1 fish could harbour neutralizing antibodies to both IHNV and VHSV. In our study, $12 \%$ of the fish tested in the double infected group showed antibodies against each of the 2 viruses at the same time. We also demonstrated that fish infected with both VHSV and IHNV developed a specific antibody reaction against each of the viruses, with kinetics and intensity (mean of $\log _{10}$ titres) similar to the antibody response in the groups infected with only one of the viruses. Likewise, Boudinot et al. (1998) demonstrated that rainbow trout receiving a combined immunization with plasmids expressing the $\mathrm{G}$ protein of VHSV and IHNV developed a double-specific antibody reaction with kinetics and intensity similar to that obtained with the single plasmid immunization. Byrne et al. (2008) studied the interference between IPNV and IHNV in rainbow trout and found no difference either in the kinetics of appearance or in the titres of the antibodies between co-infected fish and fish having received only IPNV. On the contrary, Hedrick et al. (1994) described an increase in the antibody response with respect to IHNV in trout pre-exposed to an avirulent cutthroat trout virus (CTV) compared with fish only infected with IHNV. These results indicate that the fish immune system can process multiple antigens and thus open the way for development of multivalent antiviral vaccines for fish.

This study provides support for the conclusion that the humoral immune response in rainbow trout double infected with VHSV and IHNV is similar to that observed in single infections, and that the fish are able to raise antibodies against both viruses at the same time.

Acknowledgements. The authors thank the technicians at the National Veterinary Institute for all their help, especially $M$. Eliassen, N. Nicolaisen and J. Mølgaard. We also acknowledge all our colleagues at the National Veterinary Institute for their contribution to this study. This work was undertaken while the first author held a postdoctoral research fellowship from 'Secretaría de Estado de Educación y Universidades, Ministerio de Educación, Cultura y Deporte' of Spain and cofinanced by European Social Program.

\section{LITERATURE CITED}

Alonso M, Rodríguez S, Pérez-Prieto SI (1999) Viral coinfection in salmonids: infectious pancreatic necrosis virus interferes with infectious hematopoietic necrosis virus. Arch Virol 144:657-673

Alonso M, Rodriguez Saint-Jean S, Pérez-Prieto SI (2003) Virulence of infectious hematopoietic necrosis virus and infectious pancreatic necrosis virus coinfection in rainbow trout (Oncorhynchus mykiss) and nucelotide sequence analysis of the IHNV glycoprotein gene. Arch Virol 148:1507-1521
Baudin-Laurencin F (1987) IHN in France. Bull Eur Assoc Fish Pathol 7:104

Boudinot P, Blanco M, de Kinkelin P, Benmansour A (1998) Combined DNA immunization with glycoprotein gene of viral haemorrhagic septicemia virus and infectious hematopoietic necrosis virus induces double-specific protective immunity and nonspecific response in rainbow trout. Virology 249:297-306

Bovo G, Giorgetti G, Jørgensen PEV, Olesen NJ (1987) Infectious haematopoietic necrosis: first detection in Italy. Bull Eur Assoc Fish Pathol 7:124

Brudeseth BE, Castric J, Evensen $\varnothing$ (2002) Studies on pathogenesis following single and double infection with viral hemorrhagic septicemia virus and infectious hematopoietic necrosis virus in rainbow trout (Oncorhynchus mykiss). Vet Pathol 39:180-189

Byrne N, Castric J, Lamour F, Cabon J, Quentel C (2008) Study of the viral interference between infectious pancreatic necrosis virus (IPNV) and infectious haematopoietic necrosis virus (IHNV) in rainbow trout (Oncorhynchus mykiss). Fish Shellfish Immunol 24: 489-497

Chinchar VG, Logue O, Antao A, Chinchar GD (1998) Channel catfish reovirus (CRV) inhibits replication of channel catfish herpesvirus (CCV) by two distinct mechanisms: viral interference and induction of an anti-viral factor. Dis Aquat Org 33:77-85

de las Heras AI, Rodríguez Saint-Jean S, Pérez-Prieto SI (2008) Salmonid fish viruses and cell interactions at early steps of the infective cycle. J Fish Dis 31:535-546

Dean AG, Arner TG, Sunki GG, Friedman R and others (2002) Epi Info, a database and statistics program for public health professionals. Centers for Disease Control and Prevention, Atlanta, GA

Enzmann PJ, Kurath G, Fichtner D, Bergmann SM (2005) Infectious hematopoietic necrosis virus: monophyletic origin of European isolates from North American Genogroup M. Dis Aquat Org 66:187-195

- Fregeneda-Grandes JM, Olesen NJ (2007) Detection of rainbow trout antibodies against viral haemorrhagic septicaemia virus (VHSV) by neutralisation test is highly dependent on the virus isolate used. Dis Aquat Org 74:151-158

- Hattenberger-Baudouy AM, Dalton M, Merle G, Torchy C, de Kinkelin P (1989) Serological evidence of infectious hematopoietic necrosis in rainbow trout from a French outbreak of diseases. J Aquat Anim Health 1:126-134

> Hedrick RP, LaPatra SE, Yun S, Lauda KA, Jones GR, Congleton JL, de Kinkelin P (1994) Induction of protection from infectious hematopoietic necrosis virus in rainbow trout Onchorhynchus mykiss by pre-exposure to the avirulent cutthroat trout virus (CTV). Dis Aquat Org 20:111-118

> Kärber G (1931) Beitrag zur kollektiven Behandlung pharmakologischer Reihenversuche. Arch Pharm 162: 480-483

LaPatra SE, Lauda KA, Woolley MJ, Armstrong R (1993a) Detection of a naturally occurring coinfection of IHNV and IPNV. Am Fish Soc/Fish Health Sect Newsl 21:9-10

> LaPatra SE, Turner T, Lauda KA, Walker SC, Jones GR (1993b) Characterization of the humoral response of rainbow trout to infectious hematopoietic necrosis virus. J Aquat Anim Health 5:165-171

> LaPatra SE, Lauda KA, Jones GR (1995) Aquareovirus interference mediated resistance to infectious hematopoietic necrosis virus. Vet Res 26:455-459

> LaPatra SE, Corbeil S, Jones GR, Shewmaker WD, Lorenzen N, Anderson ED, Kurath G (2001) Protection of rainbow 
trout against infectious hematopoietic necrosis virus four days after specific or semi-specific DNA vaccination. Vaccine 19:4011-4019

Lorenzen N, Olesen NJ, Vestergård Jørgensen PE (1988) Production and characterization of monoclonal antibodies to four Egtved virus structural proteins. Dis Aquat Org 4: $35-42$

Lorenzen N, Lorenzen E, Einer-Jensen K, LaPatra SE (2002) Immunity induced shortly after DNA vaccination of rainbow trout against rhabdoviruses protects against heterologous virus but not against bacterial pathogens. Dev Comp Immunol 26:173-179

Mortensen HF, Heuer OE, Lorenzen N, Otte L, Olesen NJ (1999) Isolation of viral haemorrhagic septicaemia virus (VHSV) from wild marine fish species in the Baltic Sea, Kattegat, Skagerrak and the North Sea. Virus Res 63: 95-106

> Olesen NJ, Vestergård Jørgensen PE (1986) Detection of neutralizing antibody to Egtved virus in rainbow trout (Salmo gairdneri) by plaque neutralization test with complement addition. J Appl Ichthyol 2:33-41

Olesen NJ, Jørgensen PEV (1991) Rapid detection of viral haemorrhagic septicaemia virus in fish by ELISA. J Appl Ichthyol 7:183-186

Olesen NJ, Lorenzen N, Jørgensen PEV (1991) Detection of rainbow trout antibody to Egtved virus by enzyme-linked immunosorbent assay (ELISA), immunofluorescence (IF), and plaque neutralization tests (50\% PNT). Dis Aquat Org 10:31-38

Parkingking R, Takano R, Nishizawa T, Mori K, Iida Y, Arimoto M, Muroga K (2003) Experimental coinfection with aquabirnavirus and viral hemorrhagic septicemia virus (VHSV), Edwardsiella tarda or Streptococcus iniae in

Editorial responsibility: Mark Crane,

Geelong, Australia
Japanese flounder Paralichthys olivaceus. Fish Pathol 38:15-21

Ristow SS, Lorenzen N, Vestergård Jørgensen PE (1991) Monoclonal-antibody-based immunodot assay distinguishes between viral hemorrhagic septicemia virus (VHSV) and infectious hematopoietic necrosis virus (IHNV). J Aquat Anim Health 3:176-180

Tafalla C, Rodriguez Saint-Jean S, Pérez-Prieto S (2006) Immunological consecuences of the coinfection of brown trout (Salmo trutta) with infectious hematopoietic necrosis virus (INHV) and infectious pancreatic necrosis virus (IPNV). Aquaculture 256:15-22

Vestergård Jørgensen PE, Olesen NJ, Lorenzen N, Winton JR, Ristow SS (1991) Infectious hematopoietic necrosis (IHN) and viral hemorrhagic septicaemia (VHS): detection of trout antibodies to the causative viruses by means of plaque neutralization, immunofluorescence, and enzyme-linked immunosorbent assay. J Aquat Anim Health 3:100-108

Walker PJ, Benmansour A, Dietzgen R, Fang RX and others (2000) Family Rhabdoviridae. In: Van Regenmortel MHV, Fauquet CM, Bishop DHL, Carstens EB and others (eds) Virus taxonomy: classification and nomenclature of viruses. Academic Press, San Diego, CA, p 563-583

Winton JR, Einer-Jensen K (2002) Molecular diagnosis of infectious hematopoietic necrosis and viral hemorrhagic septicemia. In: Cunningham CO (ed) Molecular diagnosis of salmonid diseases. Kluwer Academic Publishers, Dordrecht, p 49-79

Wolf K (1988) Fish viruses and fish viral diseases. Cornell University Press, Ithaca, NY

Younger JS, Whitaker-Dowling P (1994) Interference. In: Webster RG, Granoff A (eds) Encyclopedia of virology. Academic Press, San Diego, CA, p 728-732

Submitted: July 7, 2008; Accepted: October 1, 2008

Proofs received from author(s): January 9, 2009 